\title{
FUNCTIONAL ASPECT OF SEATING FURNITURE AT TAMAN FATAHILLAH, JAKARTA
}

\author{
Octaviana Sylvia Caroline'; Bambang Kartono²; \\ Yunida Sofiana $^{3}$; Titi Indahyani ${ }^{4}$ \\ 1,2,3,4 Interior Design, School of Design, Bina Nusantara University \\ J1. K. H. Syahdan No. 9, Palmeah, Jakarta 11480, Indonesia \\ 'octavianar@gmail.com; ${ }^{2}$ kartono.bambang@gmail.com; ${ }^{3}$ syunida@gmail.com; ${ }^{4}$ titi_indahyani@yahoo.com
}

Received: $17^{\text {th }}$ December 2018/ Revised: $21^{\text {st }}$ January 2019/ Accepted: $21^{\text {st }}$ January 2019

How to Cite: Caroline, O. S., Kartono, B., Sofiana, Y., \& Indahyani, T. (2019). Functional aspect of seating furniture at Taman Fatahillah, Jakarta. Humaniora, 10(1), 1-11.

https://doi.org/10.21512/humaniora.v10i1.5200

\begin{abstract}
The goal of this research was to add visual-captured data and analytical from the aspects of function as inputs for designers to be able to propose design on revitalizing the area of Taman Fatahillah. There were two problems that had been found. First, the historical street furniture had not been thought to be part of a new development of the area. Second, the newly added street furniture had not been integrated into the original purpose of Taman Fatahillah. The research used qualitative descriptive methodology with observation and visual-captured methods to collect all data needed. The conclusions are the seating furniture from the old plan has been changed its function, some of them function properly, and one of them does not function properly. Part of the newly added seating furniture in this area functionally works, but one of them does not functionally integrate into the surroundings of Taman Fatahillah as a historical revitalized public area.
\end{abstract}

Keywords: street furniture, seating furniture, Taman Fatahillah

\section{INTRODUCTION}

Taman Fatahillah in Kota Tua (Old Town), Jakarta, is the location of many communities' activities with the background in art, social, culture, and history. The integration of public space that is part of the revitalization site with new development is one of the challenges in this area. The changing function of the elements from the historical plan to new development is a challenge of new behavior to give these elements a new spirit. The additional elements are thought carefully to be fitted in its historical plan. Street furnishings create the settings for resting, sitting and eating, as well as social encounters with others (Yucel, 2016). The research variable are the seating furniture and the person/community as the user with their behavior and activities inside Taman Fatahillah.

The importance of this research is to add the recent observation, visual-captured, and functionally analyze of the street furniture focused on seating furniture in Taman Fatahillah for the incoming revitalization. The research questions that have been aroused are: (1) which street furniture is original seating furniture from the old plan of Taman Fatahillah, (2) which street furniture is the new additional seating furniture from the new development, (3) is the seating furniture convenient to be seated? (4) Does the seating furniture have the ability to gather public, (5) does the seating furniture integrate with its surroundings, and (6) has the seating furniture been used for its purpose.

The properly integrated furniture in the design of a public space creates an identity and develops a sense of place around it. According to Crankshaw Ned (Yucel, 2016), the furniture should be selected and set up based on an analysis of the site's current and desired patterns of use. While, according to Aslanoğlu and Ayşegül, the five basic criteria involved in selecting and placing items of street furniture are function (i.e. seeing how necessary an item is and how it can serve its purpose), siting and layout (i.e. deciding where each item should be places), form and appearance (i.e. making sure there a continuity or at least a linkage between the designs of different items), durability (given expected usage), and cost (Yucel, 2016).

Previous research of the community behavior pattern in Taman Fatahillah shows the results that there are behavior similarities from those using shady space, assembling with other communities, walking/ sitting while enjoying the scenery around, and interacting and performing their main activities. These behaviors need a restroom, a space of interaction, and the main activity space. Spaces such activities can form settings and environmental order which can be supplemented with element structuring public spaces recommendations such as shelters, vegetation, lights, kiosks, signage, and utility areas as physical devices supporting therein (Winata, Amiuza, \& Sujudwijono, 2015).

Data of the research could be seen in Figure 1, 2, 


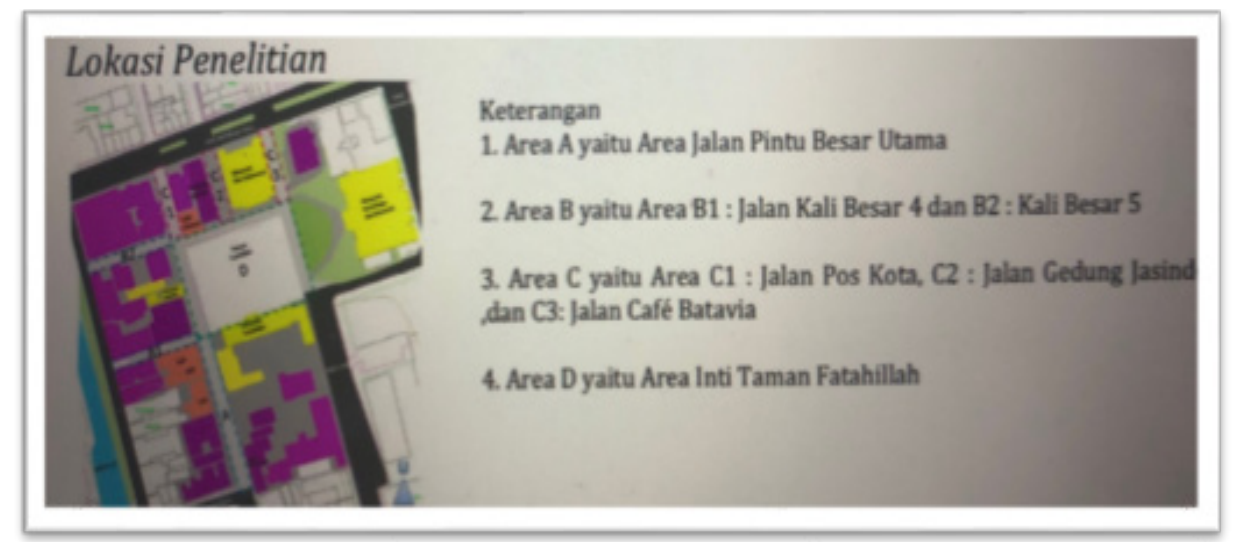

Figure 1 Location of Mapping Behavior

(Winata, Amiuza, \& Sujudwijono, 2015)

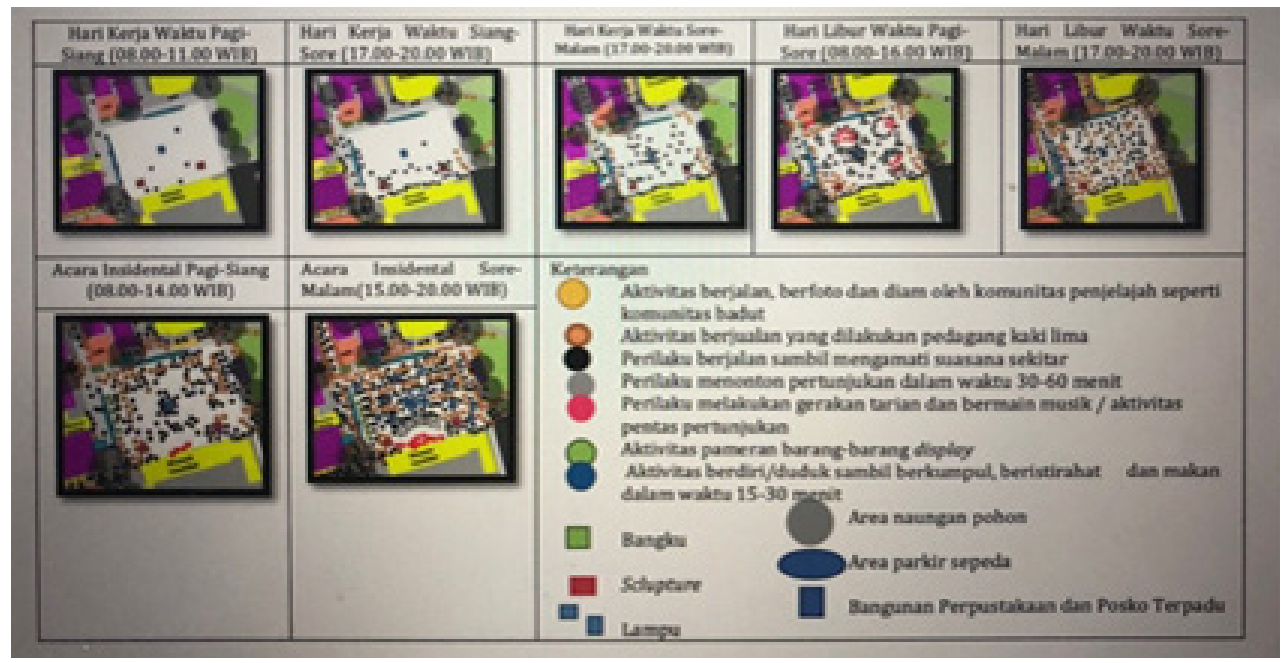

Figure 2 Behaviors Mapping in Main Area of Taman Fatahillah (Winata, Amiuza, \& Sujudwijono, 2015)
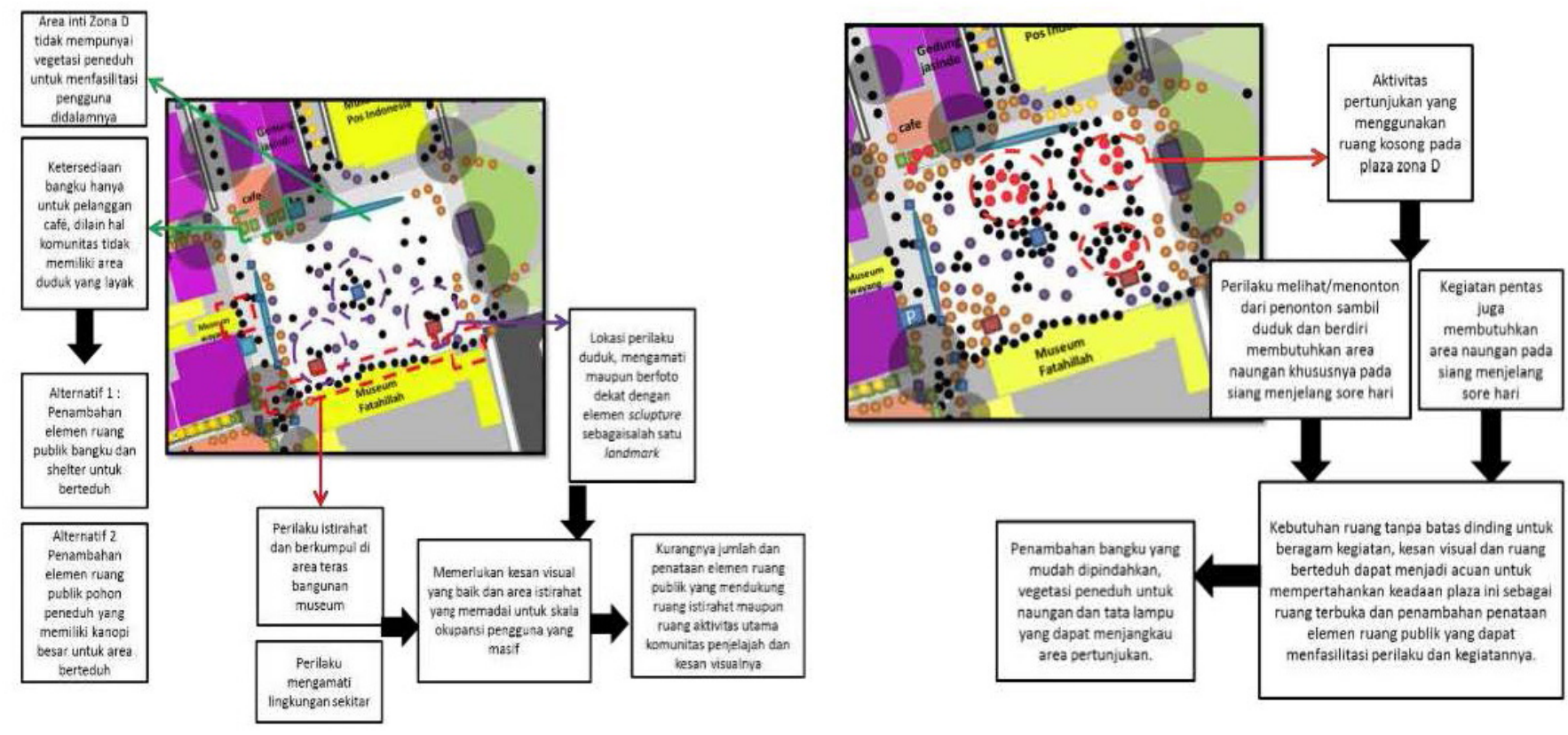

Figure 3 Behavioral Settings Analyses in Main Area of Taman Fatahillah (Winata, Amiuza, \& Sujudwijono, 2015) 

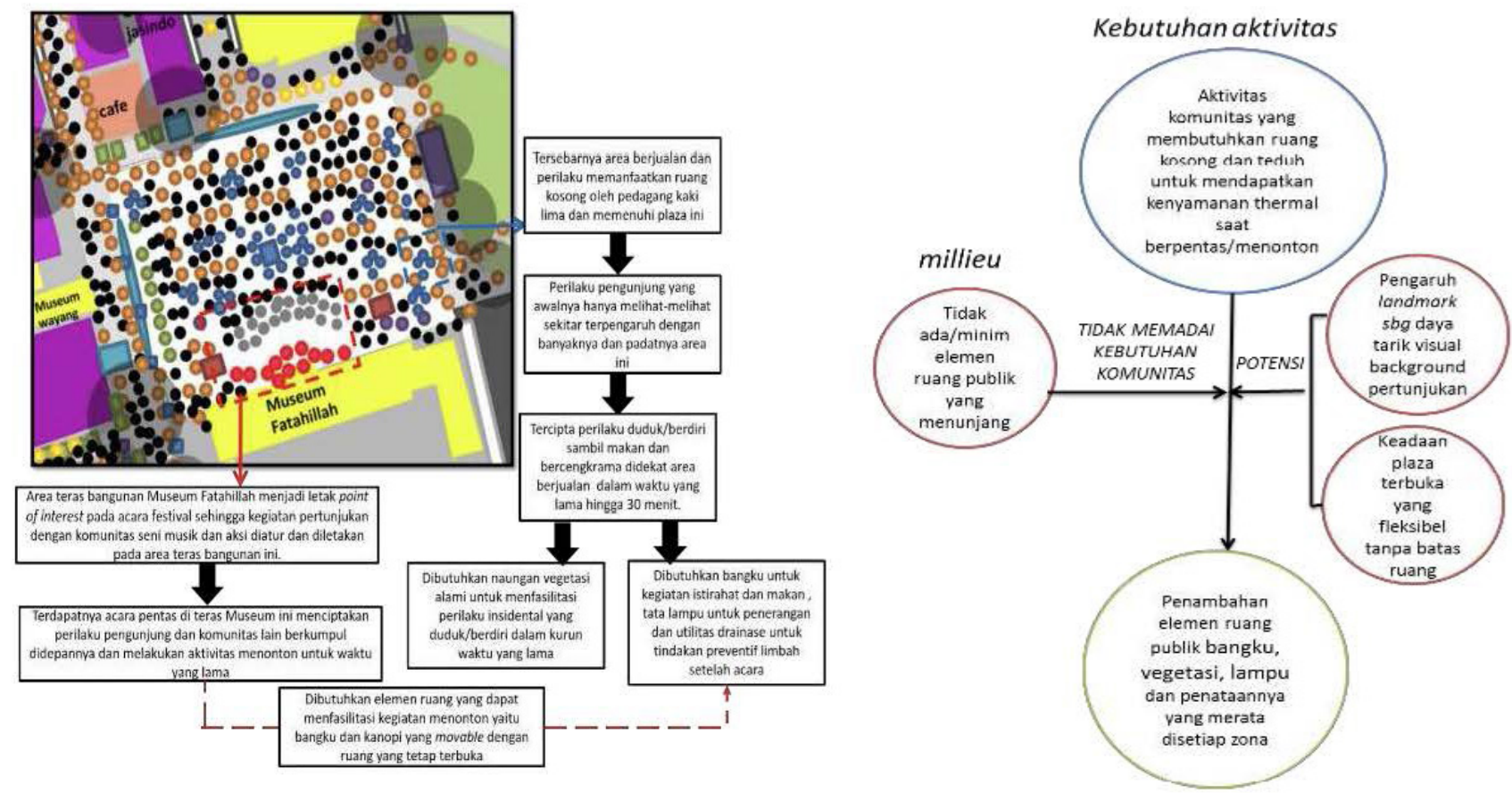

Figure 3 Behavioral Settings Analyses in Main Area of Taman Fatahillah (Continued) (Winata, Amiuza, \& Sujudwijono, 2015)

and 3. The data has been limited on the zone $\mathrm{D}$, the main area of Taman Fatahillah is (see Figure 1), the white area in the middle. The behavior mapping that related to the seating furniture includes the activity in orange dots along the entrance. It includes the activity of moveable seller with moveable chairs. The black dots in the middle include the activity of walking while looking at surroundings that could be done by bicycle. Moreover, the blue dots that are part of the building and on the border of the main garden include the activity of standing and seating while gathering more than one people, relaxing, and eating that would be possible by using part of the building or fixed seating furniture.

The main area of Taman Fatahillah is the most potential area because its openness and largeness in term the space so people who come to this area become more variable and more flexible to be developed. The range of activities from hobby, scenery tour, and sitting relaxation could be done in this area, by using chairs, shading vegetation, lighting, the special shelter of sculpture area, and terrace of the landmark building (Winata, Amiuza, \& Sujudwijono, 2015). The pattern of community behavior mapping in Taman Fatahillah shows that it has been created by the interaction among communities while they have the same behavior. This pattern could be facilitated by the area for sitting and relaxing, open interaction space, open space for viewing the landmark of Taman Fatahillah with the quality public open airy, shading, and convenient space (Winata, Amiuza, \& Sujudwijono, 2015).

Following up the previous research, it is important to study the street furniture for data and reference for creating the good public space. So it will observe one item of street furniture that is significant in Taman Fatahillah in term of its function. Street furniture refers to the objects and facilities located in urban public spaces that provide various services and functions to the public. It is one of the essential elements of the urban environment - however, many policymakers, designers, and the public neglect its importance. At the same time, it interacts with the environment by providing focus points, establishing linkages between different landscape elements, and also by coordinating with a place's identity (Siu \& Wan, 2011).

Jane Jacob, an urban planning teacher, has said that if the city's street looks interesting, the city will look interesting and vice versa. It shows that street furniture is one of a significant role in urban public open space that is created not only to accommodate a large volume of traffic but also to include design, quality, function, and aesthetic value (Aziz, Tahir, \& Ja'afar, 2012). Bulut and Atabeyoglua have said that it is a very important role to add meaning to city identities and to face lifting the society life (Aziz, Tahir, \& Ja'afar, 2012). New development should contribute to the character and legibility of public spaces as it is stated In Urban Design Guidelines, City of Ottawa 2009 (Aziz, Tahir, \& Ja'afar, 2012). According to Liley about the seating facilities in relation to sustainable design, the term itself means a design that meets present needs without compromising the ability of future generations to meet their own needs (Aziz, Tahir, \& Ja'afar, 2012). It could be a good promotional media of the city or could be good for the seating facilities that integrated with supporting element surroundings the garden (Tricahyo \& Djatmiko, 2014).

Street furniture aims to provide a place with character and identity, and also to encourage people to enjoy outdoor spaces. It also addresses specific needs, such as seating and shelter when one is waiting for transportation. It can also enhance the visual aspects, image, and identity of a site, if it is well planned and designed (Yucel, 2016). Hutton has said that many types of benches throughout history have offered unique ways of sitting and interacting with the surrounding environment. Different materials and inclines generate different social realities. Benches can either be solitary or social, exclusive or inclusive, while they are often invisible in the landscape. Public benches are actually central to the appreciation of landscapes, as they organize the scope and the scoping strategy (Green, 2013).

Open seating makes an agreeable, useable, and dynamic open environment where individuals can rest, mingle, read, or passerby. It is a basic signal that can go far 
to make an essential sense of place. Seating makes places where individuals can see and be seen. This capability to tempt individuals to stay is the sign of extraordinary and fruitful open spaces (Radwan \& Morsy, 2016). The seat has an abundant share of different designs that are not only because it is used for more than half day by the people who come but also for the diversity of the activities practiced which depends on the design of the seat itself. It is necessary to make people enjoy the seat by characteristics of achieving sitting comfortable and preserve both physical and psychological health of the man (Hendy \& El harairy, 2014).

It is important to consider the ergonomic measurement of the users for custom seating furniture to be seated conveniently. It is arranged for special purposes and behavior. Figure 4 shows the ergonomic purposes of custom seating furniture to be considered.

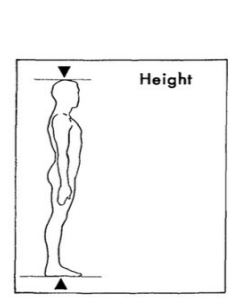

DIAGRAMS OF MEASUREMENTS
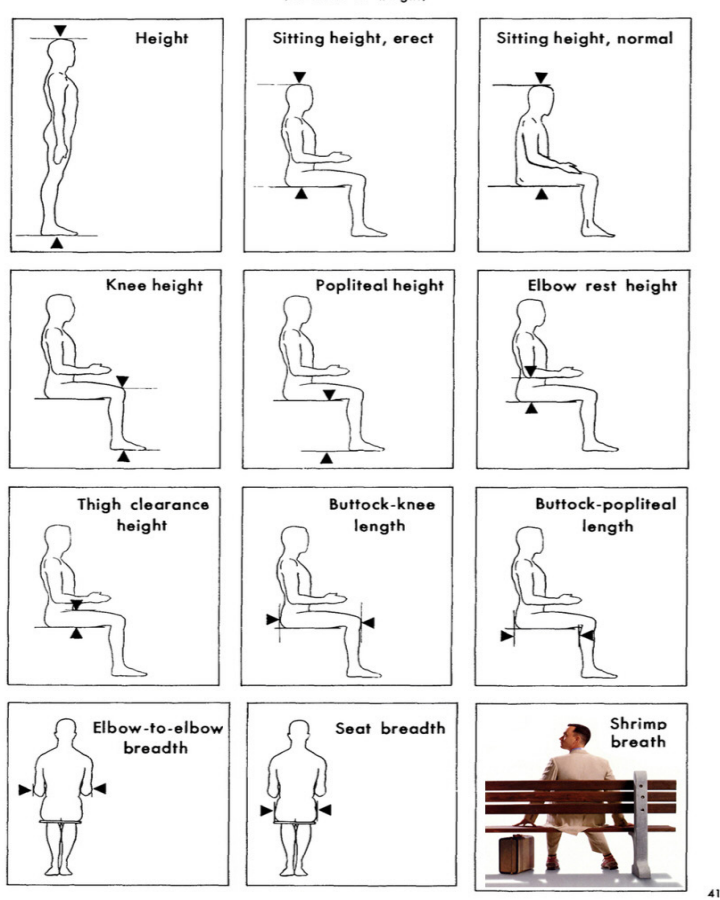

Figure 4 Diagram of Measurement for Custom Design Seating Furniture

(Radwan \& Morsy, 2016)

\section{METHODS}

This research applies qualitative descriptive methodology with observation and visual-captured methods to collect data of items that consider the seating furniture in
Taman Fatahillah, which item belongs to the old plan and which item belongs to the new development, and after that observe the convenient gesture aspect, the ability to gather public, the integration with surroundings, and the purpose of use. Data will analyze with criteria that all aspects must in positive result to be suggested as an element to be kept and developed for the future revitalization. For the item that has negative result needs to be researched on the next level from the different focus of research. Figure 5 shows the research design.

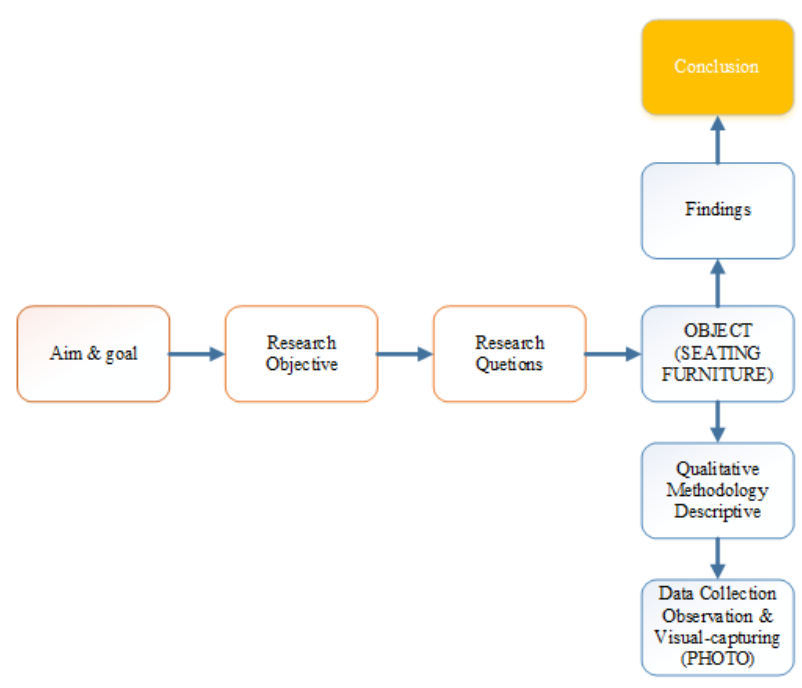

Figure 5 Research Design

\section{RESULTS AND DISCUSSIONS}

The focus is on the function of the seating furniture that has been used by people in Taman Fatahillah, whether the purpose of the items as seating furniture or not. The function is determined by the use of items by general people who come to Taman Fatahilla. It has been analyzed based on with visual captured and observation during this research on June 2018. In the term of function, this research focuses on convenient gesture aspect, ability to gather public, integrated with surroundings, and purpose of use. Based on the observation, street furniture with seating function that has been found in Taman Fatahillah are fixed chair with three types (rectangular single, rectangular long, and rounded), moveable plastic chair, mobile furniture (bicycle), statue (fountain and cannon), part of architecture building, and livable element such as the big tree. It can be seen in the second row of Table 1.

Table 1 Observation Result on the Seating Furniture on Taman Fatahillah

\begin{tabular}{llcccccc}
\hline $\mathbf{1}$ & \multicolumn{1}{c}{$\mathbf{2}$} & $\mathbf{3}$ & $\mathbf{4}$ & $\mathbf{5}$ & $\mathbf{6}$ & $\mathbf{7}$ & $\mathbf{8}$ \\
\hline No & \multicolumn{1}{c}{ Items } & $\begin{array}{c}\text { Old plan } \\
\text { Or } \\
\text { new development }\end{array}$ & $\begin{array}{c}\text { Convenient } \\
\text { gesture } \\
\text { aspect }\end{array}$ & $\begin{array}{c}\text { Ability } \\
\text { to gather } \\
\text { public }\end{array}$ & $\begin{array}{c}\text { Integrated } \\
\text { with sur- } \\
\text { roundings }\end{array}$ & $\begin{array}{c}\text { Purpose } \\
\text { of use }\end{array}$ & Result \\
\hline 1 & Fixed chair & ND & + & + & + & + & + \\
& $\begin{array}{l}\text { Rectangular single } \\
\text { Rectangular long }\end{array}$ & ND & + & + & + & + & + \\
& rounded & ND & + & + & + & + & + \\
\hline
\end{tabular}


Table 1 Observation Result on the Seating Furniture on Taman Fatahillah (Continued)

\begin{tabular}{|c|c|c|c|c|c|c|c|}
\hline 1 & 2 & 3 & 4 & 5 & 6 & 7 & 8 \\
\hline No & Items & $\begin{array}{c}\text { Old plan } \\
\text { Or } \\
\text { new development }\end{array}$ & $\begin{array}{l}\text { Convenient } \\
\text { gesture } \\
\text { aspect }\end{array}$ & $\begin{array}{l}\text { Ability } \\
\text { to gather } \\
\text { public }\end{array}$ & $\begin{array}{l}\text { Integrated } \\
\text { with sur- } \\
\text { roundings }\end{array}$ & $\begin{array}{l}\text { Purpose } \\
\text { of use }\end{array}$ & Result \\
\hline \multirow[t]{2}{*}{2} & Moveable chair & & & & & & \\
\hline & Plastic chair & ND & + & + & - & + & - \\
\hline \multirow[t]{2}{*}{3} & Mobile furniture & & & & & & \\
\hline & bicycle & ND & + & + & + & + & + \\
\hline \multirow[t]{3}{*}{4} & Statue & & & & & & \\
\hline & fountain & ND & + & + & + & + & + \\
\hline & Meriam & ND & - & - & + & - & - \\
\hline 5 & Part of architecture building & $\mathrm{OP}$ & + & + & + & + & + \\
\hline \multirow[t]{2}{*}{6} & Livable element & & & & & & \\
\hline & Big tree & $\mathrm{OP}$ & + & + & + & + & + \\
\hline
\end{tabular}

OP : Data from old plan

ND : Data from new development

$+\quad$ : Positive response on visual observation

- $\quad$ : Negative response on visual observation

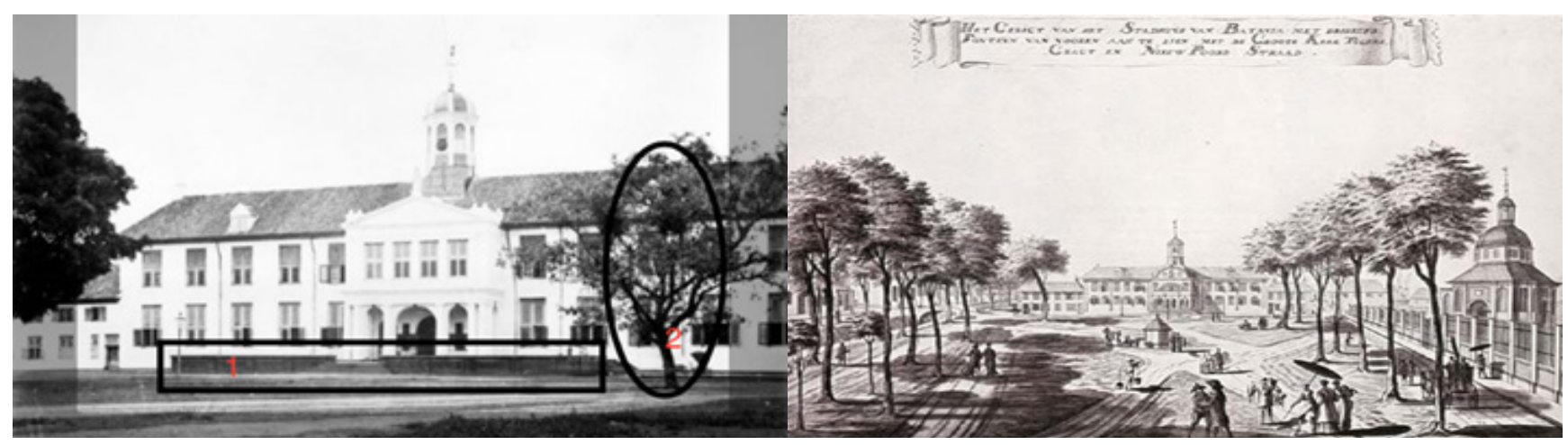

Figure 6 Photograph of Museum Fatahillah on $19^{\text {th }}$ Century (Tropen Museum Photo Collection, Retrieved from Google on December 2018)
Figure 7 Drawing of Taman Fatahillah on the Beginning of $19^{\text {th }}$ Century

(Tropen Museum Collection, Retrieved from Google on December 2018)

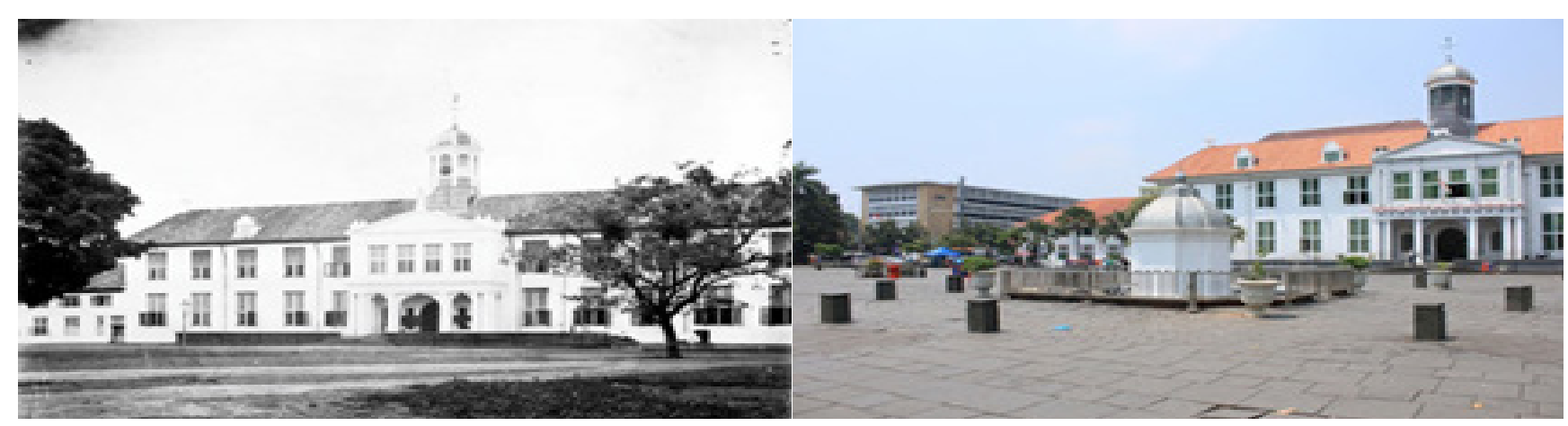

Figure 8 Museum Fatahillah in the $19^{\text {th }}$ Century (Left) and in $21^{\text {st }}$ Century (Right)

From the photo of Museum Fatahillah on the $19^{\text {th }}$ century, it could be seen that only the part of architecture (Figure 6, Number 1) and livable element, big tree (Figure 6 , Number 2) that has been on the old plan of Taman Fatahillah. For the tree, it is not necessary whether the tree is the same tree that has been seen in the old picture and the recent picture, but its scale and location remains almost the same. So, the other item of seating furniture that has been added is a new development through times.

In Figure 7, it can be seen that the trees as vegetation on both sides of the garden in front of the building. While in Figure 8, the left picture is from the 19th century and on the right image is the $21^{\text {st }}$ century. The gazebo in the middle of the garden is not built as it can be seen in the real picture 
that is taken during the $19^{\text {th }}$ century. In the $21^{\text {st }}$ century, it can be seen the replica of the fountain in the middle which looks almost the same. So based on that comparison, it is found that the replica of the fountain is part of new development.

Table 1 is the observation on the nine items with four aspects of observation (the fourth row to the seventh row from the left) and one data from the literature (the third row from the left) and the result (the eighth row from the left).

In Table 2, it can be seen the original and finding purpose of seating furniture; the number of users and also the convenient or inconvenient of the seating position. The scaling of the convenient and inconvenient of the seating furniture is scaled on the general ergonomic on visual captured (photo) and visual observation. Figure 9 shows the visual observation for seating furniture to be ergonomically convenient. It does not always need to be measured in metric or feet scaling, but it also can be done by visual observation of the gesture.

Table 2 Observation result on the seating furniture on Taman Fatahillah

\begin{tabular}{|c|c|c|c|c|c|c|}
\hline No & Photo & Items & $\begin{array}{l}\text { Original } \\
\text { Purpose }\end{array}$ & $\begin{array}{l}\text { Finding } \\
\text { Purpose }\end{array}$ & $\begin{array}{c}\text { Single user/ } \\
\text { Multiple } \\
\text { Users }\end{array}$ & $\begin{array}{l}\text { Seating } \\
\text { Position }\end{array}$ \\
\hline 1 & & $\begin{array}{l}\text { Single and long } \\
\text { rectangular fixed } \\
\text { chair }\end{array}$ & Seating & Seating & $\begin{array}{l}\text { Single and } \\
\text { multiple us- } \\
\text { ers (long) }\end{array}$ & Convenient \\
\hline 2 & & $\begin{array}{l}\text { Single and long } \\
\text { rectangular fixed } \\
\text { chair }\end{array}$ & Seating & Seating & $\begin{array}{l}\text { Single and } \\
\text { multiple us- } \\
\text { ers (long) }\end{array}$ & Convenient \\
\hline 3 & & $\begin{array}{l}\text { Single and rectan- } \\
\text { gular fixed chair }\end{array}$ & Seating & Seating & Single user & Convenient \\
\hline 4 & & $\begin{array}{l}\text { Rounded fixed } \\
\text { chair }\end{array}$ & Seating & Seating & Single user & Convenient \\
\hline
\end{tabular}


Table 2 Observation result on the seating furniture on Taman Fatahillah (Continued)

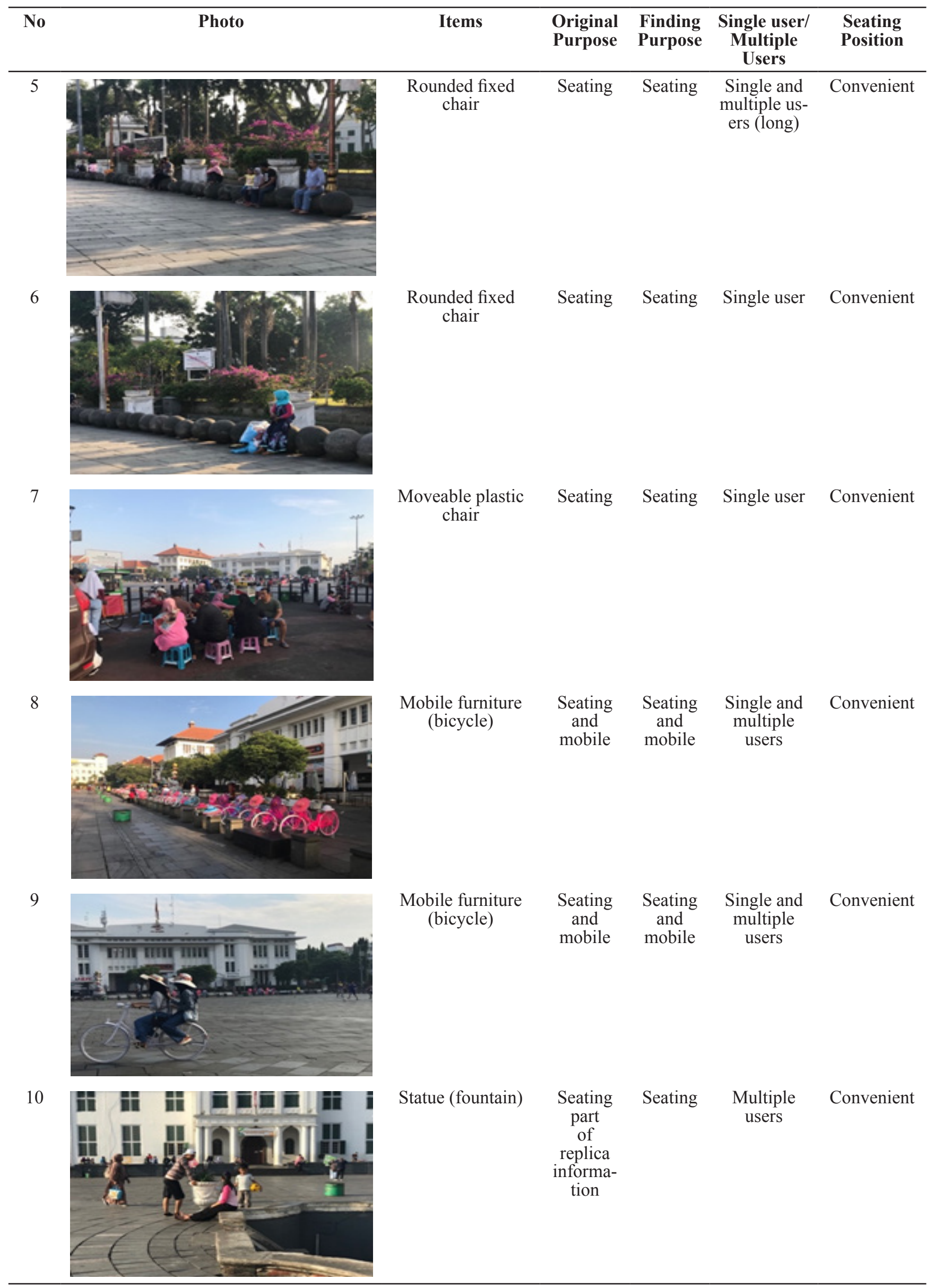


Table 2 Observation result on the seating furniture on Taman Fatahillah (Continued)

\begin{tabular}{|c|c|c|c|c|c|c|}
\hline No & Photo & Items & $\begin{array}{l}\text { Original } \\
\text { Purpose }\end{array}$ & $\begin{array}{l}\text { Finding } \\
\text { Purpose }\end{array}$ & $\begin{array}{l}\text { Single user/ } \\
\text { Multiple } \\
\text { Users }\end{array}$ & $\begin{array}{l}\text { Seating } \\
\text { Position }\end{array}$ \\
\hline 11 & & Statue (meriam) & $\begin{array}{l}\text { Statue } \\
\text { for } \\
\text { historical } \\
\text { informa- } \\
\text { tion }\end{array}$ & Seating & $\begin{array}{l}\text { Multiple } \\
\text { users }\end{array}$ & $\begin{array}{l}\text { Non Conve- } \\
\text { nient }\end{array}$ \\
\hline 12 & & Statue (meriam) & $\begin{array}{l}\text { Statue } \\
\text { for } \\
\text { historical } \\
\text { informa- } \\
\text { tion }\end{array}$ & Seating & $\begin{array}{l}\text { Multiple } \\
\text { users }\end{array}$ & $\begin{array}{l}\text { Non Conve- } \\
\text { nient }\end{array}$ \\
\hline 13 & & $\begin{array}{l}\text { Part of architecture } \\
\text { building }\end{array}$ & $\begin{array}{l}\text { Border } \\
\text { of the } \\
\text { terrace }\end{array}$ & Seating & $\begin{array}{l}\text { Multiple } \\
\text { users }\end{array}$ & Convenient \\
\hline 14 & & $\begin{array}{l}\text { Part of architecture } \\
\text { building }\end{array}$ & $\begin{array}{l}\text { Border } \\
\text { of the } \\
\text { terrace }\end{array}$ & Seating & $\begin{array}{l}\text { Multiple } \\
\text { users }\end{array}$ & Convenient \\
\hline 15 & & $\begin{array}{l}\text { Livable element } \\
\quad \text { (big tree) }\end{array}$ & $\begin{array}{l}\text { Vegeta- } \\
\text { tion }\end{array}$ & $\begin{array}{l}\text { Seating } \\
\text { and veg- } \\
\text { etation }\end{array}$ & $\begin{array}{l}\text { Multiple } \\
\text { users }\end{array}$ & Convenient \\
\hline 16 & & $\begin{array}{l}\text { Livable element } \\
\quad \text { (big tree) }\end{array}$ & $\begin{array}{l}\text { Vegeta- } \\
\text { tion }\end{array}$ & $\begin{array}{l}\text { Seating } \\
\text { and veg- } \\
\text { etation }\end{array}$ & $\begin{array}{l}\text { Multiple } \\
\text { users }\end{array}$ & Convenient \\
\hline
\end{tabular}




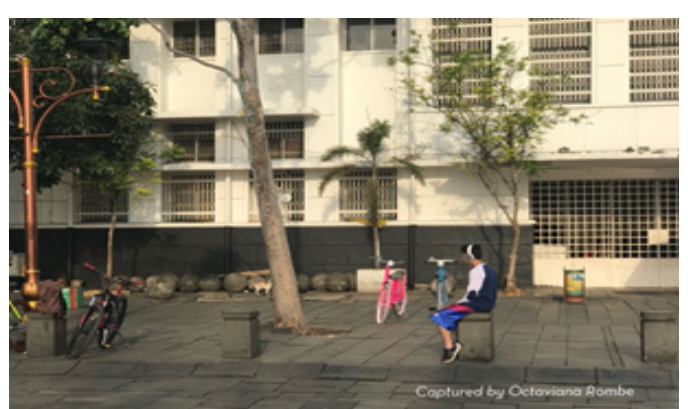

Figure 9 Single Fixed Chair

Single fixed chair in Figure 9 shows the visual data captured for the convenient ergonomics of the user. The user looks conveniently enjoyed his other activities; listening to the music while seating. The dimension of the seating is perfectly enough for a single user. The height of it is also perfectly sufficient for the length of the legs of mostly grown-up Indonesian.

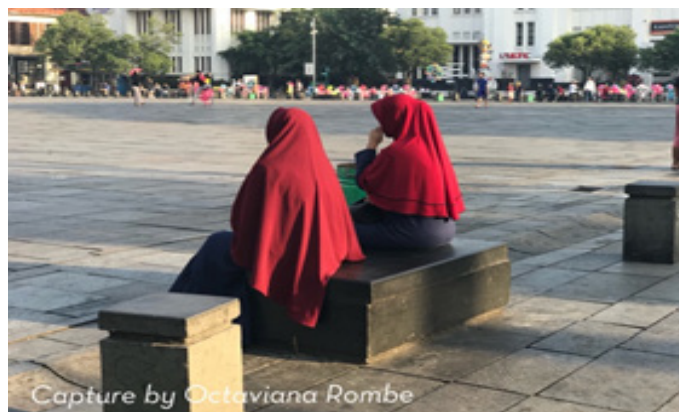

Figure 10 Long Fixed Chair

Long fixed chair in Figure 10 shows the visual data captured for the convenient ergonomic of the users. The users look conveniently sitting side by side. The dimension of the seating chair is perfectly enough for two users seating side by side with little extra space. The height of it is also perfectly sufficient for the length of the legs of mostly grown-up Indonesian.

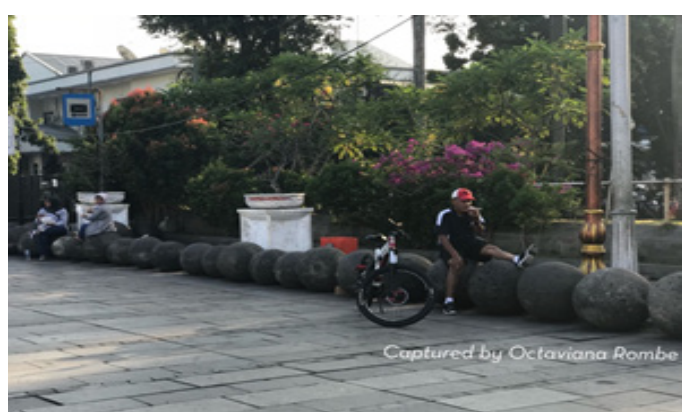

Figure 11 Rounded Fixed Chair

Rounded fixed chair in Figure 11 shows the visual data captured for the convenient ergonomics of the users. The users look conveniently sitting on the rounded shaped chair with no flat space. The dimension of the seating is perfectly enough for one user sitting to seat relax and put his leg on other next rounded chairs. The height of it is also perfectly sufficient for the length of the leg of mostly grown-up Indonesian.

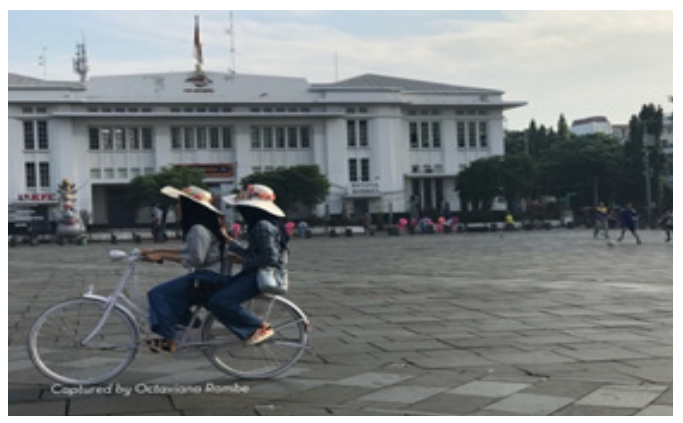

Figure 12 Moveable Seating Furniture (Bicycle)

Figure 12 shows the moveable seating furniture that is represented by bicycle. It shows the visual data that captured the convenient ergonomics of the users. The two users seating positions look conveniently while enjoying the moment and moveable scenery.

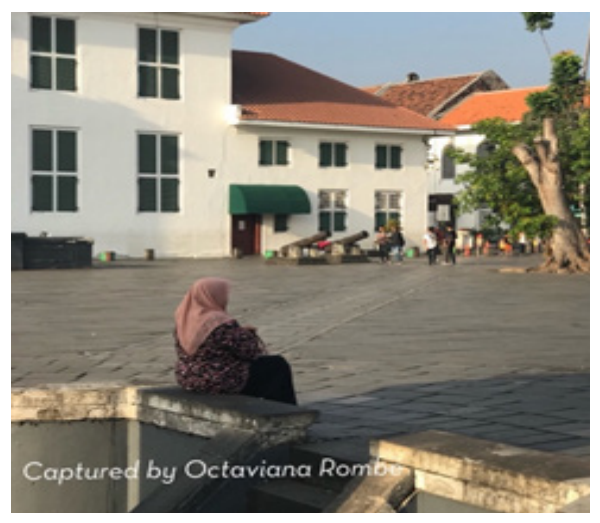

Figure 13 Statue (Fountain Replica)

Statue (fountain replica) in Figure 13 shows the visual data captured for the convenient ergonomics of the user. The user looks conveniently while looking at the scenic surroundings. The dimension of the border of the fountain is perfectly sufficient for multiple users sitting along the fountain's border. The height of it is also perfectly enough for the length of the legs of mostly Indonesian people.

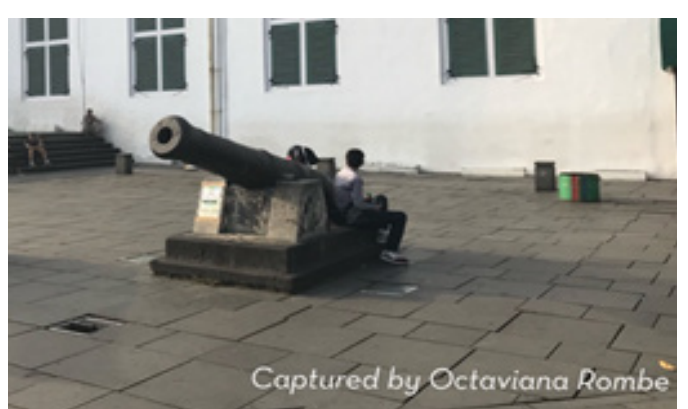

Figure 14 Statues (Cannon) 
Statue (cannon) in Figure 14 shows the visual data captured for the inconvenient ergonomics of the user. The user looks half seating on the corner while it needs to be careful for not reclining.

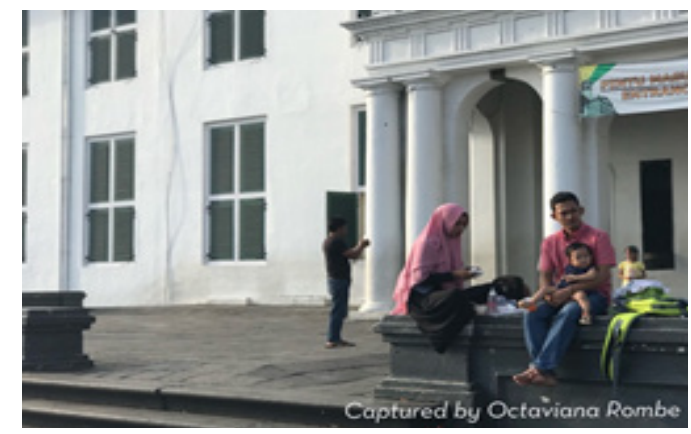

Figure 15 Part of the Architecture Building

Figure 15 shows the border of the terrace in the main architecture building in Taman Fatahillah. It shows the visual data captured for the convenient ergonomics of the users. The users look conveniently while looking at the scenic surroundings and doing their other activities. The dimension of the border of the terrace is perfectly sufficient for multiple users sitting along the terrace's border. The height of it is also perfectly enough for the length of the legs of mostly Indonesian.

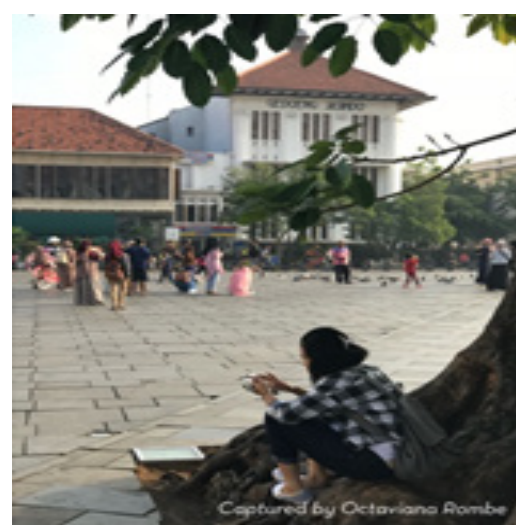

Figure 16 Livable Element

Figure 16 shows the big tree in Taman Fatahillah. The visual data capture the convenient ergonomics of the user. The user looks conveniently sitting while looking at the scenic surroundings and doing her other activities. The organic shape and dimension of the big tree are perfectly enough for the user sitting under the tree. Sitting under the natural shading of the tree makes the user enjoying the moment.

\section{CONCLUSIONS}

The conclusions of this research show that the seating furniture from the old plan that part of the street furniture in Taman Fatahillah has been changed its function due to new development and new behavior from part of the architecture.
The building does not only become seating furniture but also has functioned correctly. The part of the newly added seating furniture in this area functionally works but one of them, the moveable plastic chairs, do not functionally integrated to the surroundings of Taman Fatahillah as a historical revitalized public area. Moreover, also one of them, the statue (cannon), has been missed its purpose of use. Moveable chairs and statue (cannon) need to be researched on the next level from the different focus of research. It is suggested to research more in style and material for the moveable chairs and on signage and information for the statue to bring it back to its original purpose.

The contribution of this research is to add visualcaptured data and analytical from the aspects of function as inputs for designers to propose design on revitalizing the area of Taman Fatahillah. This research implicates that the changing behavior, the purpose, and the way people are seating would be different time to time and need to be considered in new development without leaving the study of style and material from the original design and the imagination of future design. The result of this research is limited to a certain time during the observation that had been done in 2018. With time changing, the result would be affected. It is needed future research in style and material of the new development to achieve the maximum result of the fixed chair with three types (rectangular single, rectangular long, and rounded) and mobile furniture (bicycle). It also needs future research on signage and information of the new development of statue (fountain) and the old plan on the part of architecture building and livable element (big tree) to achieve the maximum result.

\section{ACKNOWLEDGEMENT}

Thank you for Bina Nusantara University for funding this research under Hibah BINUS 2018.

\section{REFERENCES}

Aziz, A., Tahir, O. M., \& Ja'afar, M. F. (2012). Significances of sustainability street furniture design in Malaysia. Proceedings of the $2^{\text {nd }}$ International Conference on Arts, Social Sciences \& Technology Penang. Penang, Malaysia. pp. 1-9.

Green, J. (2013). The DIRT uniting the built \& natural environments. Retrieved from www.dirt.asia.org: https://dirt.asla.org/2013/12/18/the-humble-publicbench-becomes-comfortable-inclusive-and-healthy/.

Hendy, A. A., \& El harairy, Y. (2014). An ergonomic evaluation for historical seat designs. International Design Journal, 4(2), 75-83.

Radwan, A. H., \& Morsy, A. A. (2016). The importance of integrating street furniture in the visual image of the city. International Journal of Modern Engineering Research (IJMER), 4(2), 1-33.

Siu, K. W., \& Wan, P. H. (2011). Roles of street furniture in a constructed environment. International journal of the constructed environment, 1(3), 183204. Retrieved from http://elc.polyu.edu.hk/cill/ referenceMachine.aspx.

Tricahyo, F., \& Djatmiko, M. D. (2014). Perancangan fasilitas duduk di ruang terbuka kota Bandung dengan pencitraan Bandung sebagai kota kembang (studi 
kasus taman Cikapayang). Retrieved from http:// lib.itenas.ac.id/kti/wp-content/uploads/2014/03/ Jurnal-Itenas-Online-FEBRYAN-TRICAHYO322008043-EDIT.pdf.

Winata, D. P., Amiuza, C. B., \& Sujudwijono, N. (2015). Pola community behavioral setting untuk penataan ruang terbuka publik kawasan Taman Fatahillah Kota Tua Jakarta. Jurnal Mahasiswa Jurusan Arsitektur Universitas Brawijaya, 3(4), 1-9.

Yucel, G. F. (2016). Street furniture and amenities: Designing the user-oriented urban landscape. Retrieved from http://dx.doi.org/10.5772/55770. 